\title{
Make Hydrogen Whilst the Sun Shines: How to Turn the Current Momentum into a Well- Functioning Hydrogen Market?
}

\begin{abstract}
Saskia Lavrijssen and Blanka Vitéz*
The energy transition calls for greater interdependency between different energy infrastructures and energy carriers to ensure an effective integration of renewable energy into the energy system. The energy sector's legislative framework and legal safeguards, however, are still largely based on the traditional market model, designed for centrally managed, fossil fuel-based, and large-scale production units for the supply of energy. Regulation is also fundamentally based on the idea that energy markets are separate. The role of hydrogen as a flexible energy vector - allowing for interaction between different energy markets - is not yet accounted for. Regulation and integration of newer energy carriers into the energy system, like the hydrogen market, is a challenge. This is all the more so in light of the uncertainties on how the hydrogen market will develop. This contribution assesses how good regulation of the hydrogen market can be attained. For this assessment, the principles of good regulation provide a foundation for developing a normative framework to identify' good regulation' and good regulatory strategies. It is suggested that considering uncertain market developments, the use of a regulatory sandbox can offer a practical solution to assess what good regulation for the hydrogen market could entail.
\end{abstract}

\section{Introduction}

The mission to make the European Union climateneutral has reignited interest in hydrogen. ${ }^{1}$ In March 2020, the Commission announced a European Clean Hydrogen Alliance to ramp up industrial decarbonisation efforts in the EU. This alliance aims to bring investors together with governmental, institutional and industrial partners. ${ }^{2}$ In July 2020, the Commission published its hydrogen strategy, citing the need for 'an enabling regulatory framework' to reach targets concerning the installation of at least $40 \mathrm{GW}$ of renewable hydrogen electrolysers by $2030{ }^{3}$ Taking into account many other hydrogen initiatives, the EU signals that hydrogen is gaining momentum as an energy vector. ${ }^{4}$

Hydrogen's momentum is largely due to its versatility. Whilst hydrogen is still mainly extracted from fossil fuels, it can be produced in more sustainable ways, for example by way of biomass gasification and
DOI: $10.21552 / \mathrm{cclr} / 2020 / 4 / 6$

* Saskia Lavrijssen, Professor of economic regulation and market governance, Tilburg Law School, Tilburg University. For Correspondence: <S.A.C.M.Lavrijssen@tilburguniversity.edu>. Blanka Vitéz, External PhD-candidate, Tilburg University. Legal Adviser, Competition and Markets Authority. The views, opinions, and positions expressed in this article are those of the author alone and do not represent those of the Competition and Markets Authority.

1 Commission (2019) communication to the European Parliament, the European Council, the Council, the European Economic and Social Committee and the Committee of the Regions, 'The European Green Deal', COM(2019)640 final. See <https://ec.europa .eu/commission/presscorner/detail/en/fs_19_6723> accessed 24 August 2020. See $<$ https://ec.europa.eu/info/news/clean-energy -all-europeans-package-completed-good-consumers-good-growth -and-jobs-and-good-planet-2019-may-22_en> accessed 9 July
2020; see also European Commission, Clean energy for all Europeans, (Publications Office of the European Union, 2019).

2 Commission Communication to the European Parliament, the European Council, the Council, the European Economic and Social Committee and the Committee of the Regions. 'A New Industrial Strategy for Europe', COM(2020)102 final.

3 Commission Communication to the European Parliament, the Council, the European Economic and Social Committee and the Committee of the Regions, 'A hydrogen strategy for a climateneutral Europe', COM(2020)301 final, 2-3.

4 Like the Hydrogen Energy Network (an informal group of experts brought together by the Commission, see for their work <https:// ec.europa.eu/energy/topics/energy-system-integration/hydrogen/ hydrogen-energy-network-meetings_en $>$ accessed 10 August 2020. 
electrolysis. Hydrogen's significance further increases with the rise of renewable energy. The use of renewable energy sources - like wind and solar energy - may lead to situations in which too much or too little energy is generated, depending on the availability of the energy source. Electrical power can be converted into hydrogen and released again at a later date. This buffer safeguards a constant flow of energy by smoothing out imbalances between supply and demand and facilitating the integration of renewable energy into (electricity) grids. ${ }^{5}$

Despite these high expectations, the energy sector's legislative framework and legal safeguards are still largely based on the traditional market model, designed for centrally managed, fossil fuel-based, and large-scale production units for the supply of energy. ${ }^{6}$ Regulation is also fundamentally based on the idea that energy markets are separate, with different regulatory regimes for different energy carriers and energy networks. The role of hydrogen as a flexible energy vector - allowing for interaction between different energy markets - is not yet accounted for. ${ }^{7}$

Hydrogen still only accounts for less than $1 \%$ of energy consumption in the European Union. ${ }^{8}$ This

5 Paul Breeze, Hydrogen Energy Storage' in Paul Breeze (Ed.) Power System Energy Storage Technologies ( 69-77) (Academic Press 2018) 69 - 77.

6 Blanka Vitéz and Saskia Lavrijssen, 'The Energy Transition: Democracy, Justice and Good Regulation of the Heat Market' (2020) 13 Energies 5, 1-24

7 Directive (EU) 2018/2001 of the European Parliament and of the Council of 11 December 2018 on the promotion of the use of energy from renewable sources, O.J. 2018, L 328/82; Directive (EU) 2019/944 of the European Parliament and of the Council of 5 June 2019 on common rules for the internal market for electricity and amending Directive 2012/27/EU, O.J. 2019, L 158/125, for the definition of 'storage' includes hydrogen.

8 European Commission, 'Hydrogen' <https://ec.europa.eu/energy/ topics/energy-system-integration/hydrogen_en>, accessed 10 August 2020.

9 Jose Luis Moraga, Machiel Mulder, Peter Perey, 'Future Markets for Renewable Gases \& Hydrogen - What would be the optimal regulatory provisions?' (2019) CERRE Report <https://cerre.eu/ publications/future-markets-renewable-gases-and-hydrogen $>$ accessed 10 August 2020

10 ibid; Thijs van de Graaf, Indra Overland, Daniel Scholten, Kirsten Westphal, 'The new oil? The geopolitics and international governance of hydrogen' (2020) Energy Research \& Social Science 70, $1-5$.

11 Francis Bator, 'The Anatomy of Market Failure' (1958) 72 Quarterly Journal of Economics 3, 351-379. Peter Andrews, 'Are Market Failure Analysis and Impact Assessment Useful?' in Stephen Weatherill (Ed.) Better Regulation (Hart Publishing 2007) 49-82.

12 Saskia Lavrijssen, 'Independence, Regulatory Competences and the Accountability of National Regulatory' (2019) Oil Gas and Energy Law Intelligence 1. negligible position in the energy sector may be due to financial and technological reasons. The production, storage and use of sustainable hydrogen are relatively expensive, and there may not be felt an imminent need to replace fossil fuels with more sustainable - but more expensive - alternatives. ${ }^{9}$ The integration of hydrogen in the energy sector may, however, also be seriously hampered by a lack of regulation. This aspect is explored in this contribution. Lack of, or inadequate, regulation of hydrogen in the energy sector may give rise to market failures that can seriously hamper the integration of hydrogen into the energy sector. ${ }^{10}$ Appropriate regulation setting the right incentives and targeting the right problems can remedy market failures. ${ }^{11}$

This contribution assesses how good regulation of the hydrogen market can be attained, facilitating the integration of renewable energy in the energy system. For this assessment, the principles of good regulation provide a foundation for developing a normative framework for what can be identified as 'good regulation'. These principles outline a framework for the legislature, government and administrative authorities involved in economic market design. 'Traditional' energy market regulation testifies to this: well-known principles of good regulation, such as the principle of independence of regulation and supervision, are implemented in European regulation of the electricity and gas markets. ${ }^{12}$ And whilst the energy transition calls for greater interdependency between different energy markets, this is not yet accounted for. Regulation of the 'less traditional' energy markets lacks or differs substantially from the (harmonised) regulation of the traditional' energy markets. As a consequence, regulation and integration of the different markets comprising the energy sectors are a challenge. This is all the more so in light of the uncertainties on how new markets will and should develop. Good regulation is needed to ensure a holistic approach to regulating the energy sector.

The article contributes to existing literature on the regulation of the hydrogen market, by elaborating on identified regulatory gaps, possible market failures and regulatory challenges that need to be addressed. This contribution advocates for a flexible regulatory approach based on the principles of good regulation that takes into account the hydrogen market's uncertainties in terms of development. It proposes the use of a regulatory sandbox with room for experimental 
legislation to attain good regulation. ${ }^{13}$ Our analysis will draw on legal and economic theory on governance and regulation to understand different models for the regulation of the hydrogen market and the impact of good governance. The energy sector is in a crucial phase that will define how the energy transition will materialise. The findings of this research on the regulation of the hydrogen market are of relevance for the decisions that have to be taken on the integration of hydrogen in the energy sector.

\section{Hydrogen Market Development}

Hydrogen is the most abundant and lightest element in our universe. At room temperature, hydrogen is a colourless, odourless and tasteless gas that is highly combustible. Due to its lightness, pure molecular hydrogen is scarce and escapes the atmosphere if it does occur. Hydrogen, however, is commonly found in naturally existing compounds, like water and methane. It can be extracted from such compounds by separating it from the other molecules. Because many compounds contain hydrogen and hydrogen can be extracted in different ways, there are numerous (nonsite specific) techniques to produce hydrogen. ${ }^{14}$

To date, the most cost-efficient methods of hydrogen extraction involve fossil fuels. In 2019, the International Renewable Energy Agency (IRENA) estimated that around $95 \%$ of all hydrogen is generated from natural gas and coal. ${ }^{15}$ Natural gas contains large quantities of methane, which makes it ideal for hy- drogen extraction by steam methane reforming (SMR). In SMR, the reaction between methane and steam results in hydrogen, carbon monoxide and carbon dioxide $\left(\mathrm{CO}_{2}\right)$. Hydrogen extracted this way is typically referred to as 'grey' hydrogen to account for the $\mathrm{CO}_{2}$ released during extraction: every kilogram of hydrogen produced via SMR results in approximately 9.5 kilograms of $\mathrm{CO}_{2}$ as by-product. ${ }^{16}$

Hydrogen extraction from fossil fuels conceals the advantages hydrogen has in a carbon-neutral energy sector: at combustion, hydrogen results only in water vapour. If hydrogen is generated via an environmentally friendly process, it can rightfully be considered a clean fuel with a zero-emission footprint and is referred to as 'green.' ${ }^{17}$ 'Blue' hydrogen is an intermediate solution: during the production of hydrogen from fossil fuels, carbon dioxide can be captured and stored to prevent it from being released into the environment. ${ }^{18}$ Sustainable - blue and green - hydrogen are thought to be part of the pathway towards a carbon-neutral energy sector: as an energy carrier ${ }^{19}$ or as a medium for energy storage. ${ }^{20}$

\section{Hydrogen's Emergence in the European Energy Sector}

In October 2002, the High Level Group for Hydrogen and Fuel Cells Technologies, established by the European Commission and comprising of a variety of private and public sector stakeholders, outlined a vision of Europe's hydrogen future. ${ }^{21}$ It urged the
13 Commission, 'Hydrogen Energy and Fuel Cells - A vision of our future - Final report of the high level group', $\operatorname{COM}(2003)$ Special report EUR 20719 EN; European Parliament, Luc Van Nuffel, 'Sector coupling: how can it be enhanced in the EU to foster grid stability and decarbonise? (2018); IRENA, 'Hydrogen from renewable power - technology outlook for the energy transition' (2018), (n 9): EntsoF, 'EntsoG 2050 roadmap for gas grids', (2019); Hydrogen Europe, 'A Contribution to the Transition of the Gas Market' (2019); IEA, 'The Future of Hydrogen - Seizing today's opportunities International Energy Agency' (2019); IRENA, 'Hydrogen: a renewable energy perspective', (2019); World Energy Council, 'Innovation - Insights Brief 2019' (2019); Commission Communication to the European Parliament, the Council, the European Economic and Social Committee and the Committee of the Regions, 'A hydrogen strategy for a climate-neutral Europe', COM(2020)301 final; lain Staffell et al., 'The role of hydrogen and fuel cells in the global energy system' (2019) 12 Energy \& Environmental Science 2, 463-491C.; Gocke Mete and Leonie Reins, 'Governing New Technologies in the Energy Transition The Hydrogen Strategy to the Rescue?' (2020) 3 CCLR, 210-231.

14 Kaveh Mazloomi and Chandima Gomes, 'Hydrogen as an energy carrier: Prospects and challenges' (2012) 16 Renewable and Sustainable Energy Reviews 5, 3024-3033.
15 (n 12) IRENA 9.

16 ibid.

17 Green hydrogen can for example be produced via electrolysis with sustainably generated electricity.

18 Ralk Dickel, 'Blue hydrogen as an enabler of green hydrogen: the case of Germany' (2020) The Oxford Institute for Energy Studies <https://www.oxfordenergy.org/wpcms/wp-content/ uploads/2020/06/Blue-hydrogen-as-an-enabler-of-green -hydrogen-the-case-of-Germany-NG-159.pdf> accessed $10 \mathrm{Au}$ gust 2020; Frans Rooijers and Luicas Van Cappellen, 'Feasibility study into blue hydrogen - Technological, economic \& sustainability analysis' (2018) CE Delft < https://www.cedelft.eu/en/ publications/2149/feasibility-study-into-bleu-hydrogen> accessed 10 August 2020.

19 (n 14).

20 (n 5)

21 Commission, 'Hydrogen Energy and Fuel Cells - A vision of our future - Final report of the high level group', $\operatorname{COM}(2003)$ Special report EUR 20719 EN, 5. 
European Union to become a leader by 'demonstrating the benefits of a transition to a widespread use of hydrogen and fuel cells'. ${ }^{22}$ Since then, numerous groups and initiatives have been formed in pursuit of a hydrogen economy. The Joint Technology Initiative on Fuel Cells and Hydrogen (FCH 2 JU) for example, is a private-public partnership that has been set up directly following a recommendation of the High Level Group for Hydrogen and Fuel Cells Technologies. $^{23}$

FCH 2 JU is targeting the 'development of a strong, sustainable and globally competitive fuel cells and hydrogen sector in the Union' via an increase of activities relating to hydrogen production, storage and distribution. ${ }^{24}$ FCH 2 JU partners with Hydrogen Europe - a European association of $160+$ industry members, 70+ research organisations and 20+ national associations. Together, they finance and initiate numerous projects throughout the European Union. ${ }^{25}$

More recently, the European Commission proposed a Clean Hydrogen Alliance as part of its New Industrial Strategy for Europe. ${ }^{26}$ According to the Commission, the Clean Hydrogen Alliance 'will build on existing work to identify technology needs, investment opportunities and regulatory barriers and enablers. ${ }^{27}$ The Commission uses the alliance to set an investment agenda for building global leadership in the domain of hydrogen. ${ }^{28}$ For that purpose, the alliance brings investors into contact with governmental, institutional and industrial partners to facilitate smart sector integration. $^{29}$

22 ibid 12.

23 Council Regulation (EC) 512/2008 of 30 May 2008 setting up the Fuel Cells and Hydrogen Joint Undertaking, O.J. 2008, L 153/1-20 (repealed by Council Regulation (EU) 559/2014 of 6 May 2014 establishing the Fuel Cells and Hydrogen 2 Joint Undertaking, O.J. 2014, L 169/108-129).

24 Council Regulation (EU) 559/2014 of 6 May 2014 establishing the Fuel Cells and Hydrogen 2 Joint Undertaking, O.J. 2014, L 169/108-129, Article 2(1)(b).

25 Like the HEAVENN project in the Netherlands, that is aimed at developing a hydrogen valley, see <https://www.rijksoverheid.nl/ actueel/nieuws/2019/10/17/groningen-en-drenthe-krijgen-eu-geld -als-eerste-groene-waterstofregio-van-europa> accessed $10 \mathrm{Au}$ gust 2020.

26 Commission communication to the European Parliament, the European Council, the Council, the European Economic and Social Committee and the Committee of the Regions, 'A New Industrial Strategy for Europe', COM(2020)102 final.

27 ibid

28 European Commission, 'European Clean Hydrogen Alliance' (2020) <https://ec.europa.eu/growth/industry/policy/european -clean-hydrogen-alliance_en> accessed 10 August-
What these hydrogen initiatives have in common, is that they recognise the key role hydrogen can play in the energy transition and that the production and use of hydrogen should be stimulated. This ties in well with the European Green Deal. The European Green Deal is the European Union's roadmap for making the entire EU's economy sustainable and climate-neutral by $2050 .{ }^{30}$ For the energy sector, the Green Deal prioritises clean, affordable and secure energy. In its hydrogen strategy of July 2020, the Commission explains that it sees a role for hydrogen to implement the Green Deal, by complementing renewable energy. ${ }^{31}$ As a consequence, hydrogen has the potential to become a key energy vector in the EU.

\section{Ways in Which the Hydrogen Market Could Develop}

Whilst hydrogen is being stimulated on a European level, its benefits for the energy sector are also being explored on a national level by the EU's Member States. Many Member States have adopted plans and strategies to scale up the production and use of hydrogen in their energy sectors. ${ }^{32}$ The plans are largely exploratory, predominantly addressing R\&D, innovation and investments. As a result, they do not provide roadmaps for hydrogen market regulation. Whilst this is understandable in light of the many uncertainties that exist on how the hydrogen market

29 (n 26); (n 28).

30 Commission communication to the European Parliament, the European Council, the Council, the European Economic and Social Committee and the Committee of the Regions, 'The European Green Deal', Annex, COM(2019)640 final.

31 Commission communication to the European Parliament, the Council, the European Economic and Social Committee and the Committee of the Regions, 'A hydrogen strategy for a climateneutral Europe', $\operatorname{COM}(2020) 301$ final

32 See for example for Belgium: Isabel François et al., 'Het potentieel voor groene waterstof in Vlaanderen - Een routekaart' (2018) <https://www.hinicio.com/file/2018/11/Rapport-Vlaams -potentieel-groene-waterstof.pdf $>$ accessed 10 August 2020; Ministry for the Ecological Transition and the Demographic Challenge, 'Public consultation on the role of hydrogen' (2020) $<$ https://energia.gob.es/en-us/Paginas/index.aspx> accessed 10 August 2020; German Federal Ministry for Economic Affairs and Energy, 'The National Hydrogen Strategy'; Dutch Government, 'Klimaatakkoord' (2019); Afhypac, 'Developing Hydrogen for the French Economy' (2018); UK Committee on Climate Change, 'Reducing UK emissions - Progress Report to Parliament' (2020) $<$ https://www.theccc.org.uk/publication/reducing-uk-emissions -2020-progress-report-to-parliament/> accessed 24 August 2020 
will develop, it makes it challenging to anticipate good regulation of the hydrogen market.

This uncertainty is reflected in the European hydrogen strategy presented by the Commission in July 2020. The strategy states that a regulatory framework is needed, which allows for access to hydrogeninfrastructure on a non-discriminatory basis and neutrality of network operators. Whilst the Commission states that these must be guaranteed to obtain a competitive, cross-border market, it does not elaborate further on these requirements. ${ }^{33}$ This lack of clear instructions may slow down the development of both the hydrogen market and its market regulation. However, in spite of uncertainty on how the hydrogen market may develop, several predictions can be made on the basis of reports that have been published in recent years. ${ }^{34}$ This results in realistic scenarios that have to be taken into account as early as possible in the regulatory choices to be made.

\section{Hydrogen: A Significant Storage Medium and Energy Carrier in the Energy Sector}

The production and use of renewable energy need to increase substantively over the coming years. ${ }^{35}$ Renewable energy is relatively unpredictable compared to energy from fossil fuels, as not all renewable energy sources are constant due to fluctuating weather circumstances. This is where hydrogen is most likely to step in. Hydrogen can provide a corrective to the volatility of renewable energy by offering stability and resilience through storing (or buffering) energy generated during supply peaks. ${ }^{36}$ As a storage medium, hydrogen may link different parts of the energy sector via energy conversion. Additionally, energy generated during supply peaks may also be used to generate green hydrogen for direct use.

Hydrogen could also become a stand-alone energy carrier similar to electricity. ${ }^{37}$ With appropriate risk-management in place, hydrogen may be used for transport, heating, cooking, to produce electricity (from storage), etc. This will require sufficient supply and demand and the availability of an energy infrastructure to connect supply and demand. ${ }^{38}$ The use of hydrogen as a storage medium and as an energy carrier implies that transportation of hydrogen will become important. Hydrogen can be transport- ed via pipes (as a gas), by trucks and rail (as a gas or liquid) or over water (as a liquid).$^{39}$ Numerous locations could become production sites because hydrogen can be produced from different sources. ${ }^{40}$ The method of transportation will differ accordingly, and as a consequence, it will become important to invest in transportation methods to ensure that supply and demand can meet.

For the near future, where blue hydrogen production is expected to grow fastest, and the use of grey hydrogen will be limited, transportation of captured $\mathrm{CO}_{2}$ will become more important. This will also require a transportation network to ensure that captured $\mathrm{CO}_{2}$ will end up in the right place.

\section{The Hydrogen Market Could Evolve into a European Market}

It is expected that the hydrogen market will become at least a European market in size. This is a consequence of the need to match supply and demand and the expectation that it is unlikely that national hydrogen markets will suffice. ${ }^{41}$ Rather, a European market will emerge, and if interconnectedness allows,

33 Commission Communication to the European Parliament, the Council, the European Economic and Social Committee and the Committee of the Regions, 'A hydrogen strategy for a climateneutral Europe', $\operatorname{COM}(2020) 301$ final, 16; see also (n 13) Mete and Reins.

34 See for example Commission, 'Hydrogen Energy and Fuel Cells A vision of our future - Final report of the high level group', $\operatorname{COM}(2003)$ Special report EUR 20719 EN; (n 13) Van Nuffel; (n 13) IRENA; (n 9); (n 13) EntsoF; (n 13) Hydrogen Europe; IEA ( 13) ; (n 13) IRENA; (n 13) World Energy Council; Commission

35 Commission communication to the European Parliament, the European Council, the Council, the European Economic and Social Committee and the Committee of the Regions, 'The European Green Deal', COM(2019)640 final; and see Eurostat, 'Renewable energy statistics' (2020) < https://ec.europa.eu/eurostat/ statistics-explained/index.php/Renewable_energy_statistics\#Share _of_renewable_energy_almost_doubled_between_2004_and _2018> accessed 10 August 2020.

36 IRENA (n 13) 25-33; (n 3) 6 .

37 IEA (n 13) 32

38 (n 3), 14

39 See Hydrogen Europe, Hydrogen Transport \& Distribution (2020) $<$ https://hydrogeneurope.eu/hydrogen-transport-distribution> accessed 10 August 2020

40 IRENA (n 13) 30.

41 See Hydrogen Economy Outlook, 'Key Messages' (2020) <https:// data.bloomberglp.com/professional/sites/24/BNEF-Hydrogen -Economy-Outlook-Key-Messages-30-Mar-2020.pdf> accessed 13 August 2020 
perhaps a global market to even better match supply and demand. ${ }^{42}$

A European market requires cross-border transport and trading possibilities for hydrogen and means that market fragmentation due to conflicting regulations or regulatory gaps is undesirable. Because hydrogen production is less site-specific than fossil fuel extraction, cross-border trade is all the more important. ${ }^{43}$ Cost-effective sustainable hydrogen production sites need to be connected with the rest of the world to spur production of sustainable hydrogen and the matching of supply and demand.

\section{Hydrogen Regulation in the EU - Which Way to Go?}

Market regulation related to hydrogen is largely absent in the EU, save for several rules that indirectly affect market regulation. An example of indirect regulation is the Renewable Energy Directive that requires Member States to collectively ensure that the share of energy from renewable sources in the Union's gross final consumption of energy in 2030

\footnotetext{
42 IRENA (n 13) 35-37.

43 ibid 28-30.

44 Directive (EU) 2018/2001 of the European Parliament and of the Council of 11 December 2018 on the promotion of the use of energy from renewable sources, OJ L 328, 21.12.2018, 82-209; See Art 3(1) of the Renewable Energy Directive.

45 Art 20 of the Renewable Energy Directive.

46 Art 19 of the Renewable Energy Directive.

47 Art 2(60) of the Internal Market Electricity Directive.

48 Robert Baldwin et al., Understanding Regulation - Theory, Strategy, and Practice (Oxford Scholarship Online, 2011).

49 Bator (n 11).

50 J.A Den Hertog, 'Review of Economic Theories of Regulation' (2010) 10-18, 2010; K Arrow, 'The Organization of Economic Activity: Issues Pertinent to the Choice of Market Versus Nonmarket Allocation' in R H Haveman and Margolis, (Eds.), Public Expenditure and Policy Analysis (Rand MacNally College Publishing Company 1970).

51 Tony Prosser, 'Regulation and Social Solidarity' (2006) 33 Journal of Law and Society 3, 364-387; see also Anna Butenko and Pierre Larouche, 'Regulation for innovativeness or regulation of innovation?' (2015) 7 Law, Innovation and Technology 1, 52-82.

52 (n 48) 15.

53 See European Commission, 'Energy poverty' (2019<https://ec .europa.eu/energy/topics/markets-and-consumers/energy -consumer-rights/energy-poverty_en?redir=1 > accessed $10 \mathrm{Au}$ gust.

54 Marga Edens and Saskia Lavrijssen 'Balancing Public Values During the Energy Transition - How Can German and Dutch DSOs Safeguard Sustainability?' (2019) Energy Policy 128, 57-65.

55 Vitez and Lavrijssen (n 6) 1-24.
}

is at least $32 \%{ }^{44}$ This has implications for hydrogen regulation because the Renewable Energy Directive requires that gas grids have to facilitate the integration of gas from renewable sources. ${ }^{45}$ The use of blends of hydrogen and natural gas thus brings hydrogen gas partially within the scope of 'regular' EU gas regulation. The Renewable Energy Directive also opened the way for the use of guarantees of origin for hydrogen. ${ }^{46} \mathrm{~A}$ third example is the Internal Market Electricity Directive. By defining 'energy storage' as 'the conversion of electrical energy into a form of energy which can be stored, the storing of such energy, and the subsequent reconversion of such energy into electrical energy or use as another energy carrier', it catches hydrogen energy storage. ${ }^{47}$

Despite the absence of comprehensive hydrogen market regulation, hydrogen is increasingly included in future energy scenarios. It is therefore relevant to consider whether possible market failures are hindering the development of a well-functioning hydrogen market. ${ }^{48}$

A failing market does not provide activities desired by society or does not halt undesirable activities. ${ }^{49}$ Economic theory justifies public intervention to correct market failures, for example by way of regulation. ${ }^{50}$ Market regulation shapes the structure of a market and the interactions taking place on that market. As a second source of regulatory legitimacy, Prosser (2006) identifies social solidarity in addition to economic theory related to market failures. ${ }^{51}$ Apart from remedying market failures, regulation may thus also pursue social aims. ${ }^{52}$ This is already recognised in the European energy sector. Article 194 TFEU specifically calls EU regulation to 'ensure security of supply in the Union' and access for all to affordable energy is considered to be indispensable in line with the EU's aim to eradicate energy poverty. ${ }^{53}$ These public values of universal access, security of supply and the affordability of sustainable energy demonstrate that regulation of the energy sector is partially driven by social aims. ${ }^{54}$ The emergence of the principles of energy justice and energy democracy further underlines the importance of the social aspects of energy regulation. ${ }^{55}$

\section{Regulatory Strategies}

The absence of comprehensive market regulation not only draws attention to market failures and reasons 
to regulate but also raises the question of which regulatory strategy is best equipped to remedy these market failures. Baldwin, Cave and Lodge (2011) differentiate between eight different types of regulatory strategies. ${ }^{56}$ Some of these strategies are specifically relevant in the context of emerging markets and offer possible regulatory routes that the EU and national government can take to foster the establishment of the hydrogen market. For that purpose, the following regulatory strategies will be further explored in section 5 :

- Incentive-based regulation - this type of regulation incentivises desired behaviours by imposing taxes, grants and subsidies to make desired behaviour more rewarding. ${ }^{57}$

- Market-harnessing controls - a legal regime in which competition is protected by the government, without the use of detailed ex ante regulations, to create conditions to ensure that the market can deliver what is desired. ${ }^{58}$

- Government direct action - means that a government takes matters in its own hands or designs a market in a way that undesirable outcomes cannot occur. ${ }^{59}$

- Command and control regulation - a government exercises influence by imposing mandatory ex ante standards that are backed by sanctions. ${ }^{60}$

\section{Principles of Good Regulation}

The next consideration is on how to guarantee that regulation delivers the expected results and facilitates a well-functioning hydrogen market. The framework provided by the principles of good regulation provides guarantees for high-quality regulation. High-quality regulation promotes a stable and predictable regulatory framework which is an important condition for an attractive investment climate. ${ }^{61} \mathrm{Ac}$ cording to the OECD, good regulatory outcomes depend not only on well-designed rules but also on welldesigned independent regulators. ${ }^{62}$ The principles of good regulation thus shape regulations and regulators alike.

In the EU, the principles of good regulation (or good governance, as they are also referred to) have been shaped in case law and practice. They embody the essentials for good regulation and direct the relationship between the government (in the broadest sense of the word) and society. ${ }^{63}$ More recently, 'bet- ter regulation' efforts in the EU have focussed on how the principles of good regulation influence rulemaking in the EU. ${ }^{64}$ The principles of good regulation represent values that European regulation embodies, corollaries of the rule of law and democracy. ${ }^{65}$ More recently, the concepts of energy justice and energy democracy have also been identified as colouring the principles of good regulation in the energy sector. ${ }^{66}$ Energy justice and energy democracy include the public interests of security of supply, affordability and universal access, already well-embedded in energy law. While the concepts of energy democracy and energy justice flow from a growing social movement, elements covered by the concepts can be found in European and national policy documents and regulations. $^{67}$

There is a growing concern that justice and democracy have to be further embedded in energy sector regulation $^{68}$ and the principles of good regulation should aim at realising these fundamental values. The principles of good regulation are well-placed to do so. They are flexible, whilst at the same time, they also act as minimum boundaries that shape regula-

56 (n 49) ch 7; see also European Commission, 'Study on regulatory incentives for investments in electricity and gas infrastructure projects - Final Report, <https://ec.europa.eu/energy/sites/ener/ files/documents/MJ0614081ENN_002.pdf> accessed 27 September 2020.

57 (n 48) 111

58 ibid 114

59 ibid 122.

60 ibid 107

61 (n 6) $1-24$

62 OECD Best Practice Principles for Regulatory Policy-The Governance of Regulators; OECD Publishing: Paris, France, 2014.

63 Henk Addink, Good Governance: Concept and Context. (Oxford Scholarship Online 2019) chpt 2.

64 European Commission, 'Better regulation: why and how' (2017) $<$ https://ec.europa.eu/info/law/law-making-process/planning-and -proposing-law/better-regulation-why-and-how_en>

65 Henk Addink (n 63

66 (n 6); Kirsten Jenkins, ,Energy Justice, Energy Democracy and Sustainability: Normative approaches to the Consumer Ownership of Renewables' in J Lowitzsch (Ed.), Energy Transition: Financing Consumer Co-Ownership in Renewables (Palgrave Macmillan 2017) 79-97.

67 Sören Becker and Matthias Naumann, 'Energy democracy: Mapping the debate on energy alternatives' (2017) 11 Geography Compass 8; Lee Godden et al., Energy Justice and Energy Law (Oxford Scholarship Online 2020) Imelda Maher and Stefan Oana, 'Delegation of powers and the rule of law: Energy justice in EU energy regulation' (2019) Energy Policy, 128, 84-93.

68 John Barry and Noel Healy, 'Politicizing energy justice and energy system transitions Fossil fuel divestment and a "just transition"' (2017) Energy Policy, 108, 451-459. 
tion. This allows for concerns of justice, democracy and other values, such as efficiency, to be taken into account. Below, six principles of good regulation are concisely presented in the context of the energy sector. These principles are relevant for guiding policy makers and regulators in finding a balance between potentially conflicting interests of energy regulation. ${ }^{69}$

\section{Transparency}

In the context of economic regulation, transparency stems from the principle of democracy and provides for legitimacy of a regulatory authority's independence and contributes to the effectiveness of economic regulation. ${ }^{70}$ This applies throughout the entire regulation chain: from drawing up regulation to enforcement. ${ }^{71}$ For regulatory authorities, the principle requires them to be open to stakeholders about their objectives, processes, records and decisions. From a legal perspective, transparency requires unambiguous rules and decisions that market players and stakeholders have access to and understand, so that they can act accordingly. This flows from the requirements of good administration. In this fashion, trans-

69 See for a more comprehensive overview also (n 6) 1-24

70 Margot Aelen, 'Beginselen van Goed Markttoezicht-Gedefinieerd, Verklaard en Uitgewerkt Voor Het Toezicht op de Financiële Markten' (2014) Boom Juridische Uitgevers, 333-334; S Prechal et al., 'Transparency: A General Principle of EU Law?' in Ulf Bernitz et al., (Eds.), General Principles of EC Law in a Process of Development (Kluwer Law International, 2008) 205.

71 Leigh Hancher et al, 'Principles of Good Market Governance' (2003) XLIX Competition and Regulation in Network Industries 2, $339-374$.

72 OECD Best Practice Principles for Regulatory Policy-The Governance of Regulators; OECD Publishing: Paris, France, 2014, ch 4.

73 Andre Nollkaemper and Deirdre Curtin, 'Conceptualizing Accountability in International and European Law' (20017) Netherlands Yearbook of International Law 36, 3-20.

74 Which ties in with the right to effective judicial protection.

75 Leigh Hancher et al (n 71); (n 72) ; (n 63); Mark Bovens, 'Public Accountability' in E. Ferlie et al., (Eds.), The Oxford Handbook of Public Management (Oxford Handbooks Online, 2007).

76 (n 72) chapter 2.

77 See also Directive (EU) 2019/944 on common rules for the internal market for electricity and amending Directive 2012/27/EU (recast) and Directive 2009/73/EC concerning common rules for the internal market in natural gas.

78 (n 71); Saskia Lavrijssen and Annetje Ottow, 'Independent supervisory authorities: a fragile concept' (2012) 39 Legal Issues of Economic Integration 4, 419-445.

79 (n 72), ch 2. parency increases predictability for market players (and other stakeholders) by requiring that regulatory action is published and clear. ${ }^{72}$

\section{Accountability}

Accountability obliges regulatory authorities to render account about their actions and thereby protects the interests of stakeholders. ${ }^{73}$ Transparency is positively related to accountability, in that increased transparency allows actions to be scrutinised, enabling more forms of accountability. The principle of accountability implies the existence of certain standards, targets or values, that will determine whether the regulatory authority being held accountable is performing satisfactorily within its mandate. There are different types of accountability mechanisms, such as accountability vis-à-vis stakeholders in administrative procedures, judicial accountability in legal proceedings at the court ${ }^{74}$ and political accountability vis-à-vis the responsible minister and/or parliament. Accountability also implies the existence of consequences in case of unsatisfactory performance. $^{75}$

\section{Independence}

The principle of independence, as embedded in EU law, requires regulators to be legally, financially and functionally independent from market parties and other stakeholders to prevent undue influence and regulatory capture. ${ }^{76} \mathrm{~A}$ further element of this principle requires a degree of independence from government and is still somewhat controversial. ${ }^{77}$ Political independence involves a distinction between choices made by the regulatory authority and by the government. Policy choices of a more general nature, such as sustainability goals and policies to protect vulnerable consumers fall within the realm of politics. Decisions that are of an operational and technical nature and that more directly regulate market entry and market behaviour- such a tariff methodology - are better handled by an independent regulatory authority that is an expert. ${ }^{78}$ The OECD notes that no, or less political influence on decisions that fall within the regulatory authority's mandate, increases the trust of the regulated entities in the decisions and interventions that the regulator makes. ${ }^{79}$ 
From a perspective of accountability, a high degree of - especially political - independence may seem imprudent, in that it increases the risk of a regulatory authority straying away from its mandate. This inherent tension between the two principles can be mitigated by comprehensive accountability mechanisms and transparency levels.

\section{Participation}

The principle of participation is gaining prominence in the EU. Illustrative is the 'Have your say' initiative of the EU that invites citizens to react online to pol icy and legislative proposals. ${ }^{80}$ This initiative is an example of procedural participation engaging stakeholders in policy-making and administrative decision-making. Procedural participation enhances the confidence of stakeholders in regulation and regulatory decision-makings and may increase support for local renewable energy projects. ${ }^{81}$ Enforceable rights of participation are better placed to increase the legitimacy of regulatory outcomes as decision-makers can be held accountable by the courts regarding the way they comply with participation requirements. ${ }^{82}$ We have coined the term substantive participation for involvement that rather than being a tick-the-boxexercise, refers to an on-going process between stakeholders and an input receiving entity (like a regulatory authority or a market player) and may even imply financial participation or local ownership of citizens in local renewable energy projects. ${ }^{83}$ In line with the increased importance of energy justice and energy democracy, substantive and enforceable participation rights have also gained importance in energy-related EU regulation - like anchoring the role of 'renewable energy communities' as defined in the Renewable Energy Directive. ${ }^{84}$

\section{Effectiveness}

Today, the principle of effectiveness is interpreted as applying to 'EU norms imposing obligation, thus enhancing their enforcement'. ${ }^{85}$ This is confirmed by the Commission: '[p]olicies must be effective and timely, delivering what is needed on the basis of clear objectives, an evaluation of future impact and, where available, of past experiences. Effectiveness also depends on implementing EU policies in a proportion- ate manner and on taking decisions at the most appropriate level. $^{, 86}$ The principle of effectiveness is binding in so far as it relies on the binding nature of the elements relating to the principles of subsidiarity and proportionality. ${ }^{87}$ Effectiveness should act as an obligation resting upon both legislator and/or regulator when drafting legislation, policies and taking decisions to assure that the appropriate administrative level is involved and that all action taken is necessary, suitable to reach the goals defined and proportionate to the aim it serves. ${ }^{88}$

\section{Efficiency}

In order to guarantee a market that operates efficiently, intervention should take place when market failures arise. A market failure justifies intervention, and only in so far as it remedies the perceived market failure at the lowest level of costs for the public. ${ }^{89}$ Viewed in this way, the principle of efficiency is strongly linked to the principle of subsidiarity, as found in Article 5 TEU. ${ }^{90}$ Subsidiarity in the European Union means that powers shared between the European Union and its Member States are executed at the lowest appropriate level of governance. This also applies to efficient market organisation: governance is lim-

80 See European Commission, 'Welcome to Have your Say' (2012) <https://ec.europa.eu/info/law/better-regulation/have-your-say> accessed 10 August 2020

81 Commission, 'European Governance: A White Paper', $\operatorname{COM}(2001) 428$ final, 7.

82 Alberto Alemanno, 'Unpacking the Principle of Openness in EU Law - Transparency, Participation and Democracy' (2014)39 European Law Review (1), 72-90.

83 (n 6)

84 See Art 22 Directive (EU) 2018/2001 of the European Parliament and of the Council of 11 December 2018 on the promotion of the use of energy from renewable sources (Text with EEA relevance.)

85 Takis Tridimas, 'The general principles of EU law and the Europeanisation of national laws' (2020) 13 Review of European Administrative Law 2, 5-31

86 Commission, 'European Governance: A White Paper', $\operatorname{COM}(2001) 428$ final, 7.

87 See Art 5 TEU, the principles of subsidiarity and proportionality apply to (the use of) all EU competences.

88 (n 70) 153; see also OECD, 'Recommendation of the Council on Regulatory Policy and Governance' (2012) 13.

89 (n 50), 5-21.

90 Aurdlian Portuese, 'The principle of subsidiarity as a principle of economic efficiency' (2010) Columbia Journal of European Law. 
ited to facilitating necessary interventions by the best-placed actors in order to attain a well-functioning market.

In addition to these economic grounds, a market failure in the energy sector may come in the form of public values that will not be pursued when left to the 'free market'. 91 The definition of an efficient European energy sector includes certain values that society wants to safeguard. These non-market values are equally relevant in deciding whether intervention is necessary. ${ }^{92}$ For the energy sector to be efficient, it can thus be argued that the classic, efficient market curve incorporates the values of the energy sector: reliable, affordable, sustainable energy for all European citizens. $^{93}$

The relevance of the principle of efficiency is highlighted by the many changes instigated by the energy transition. For regulatory authorities to be up to speed with innovations and developments taking place in the energy sector, efficient - flexible - regulation and action are key. ${ }^{94}$ Regulation should not be set in stone but should be able to accommodate technological innovations that are leading to a more efficient and just energy transition.

\section{Regulatory Options Explored: A Regulatory Sandbox}

\section{Market Failures and Regulatory Approaches}

As stated above, regulation mainly targets market failures and aims at socially desirable outcomes protecting vulnerable consumers in the energy sector. This indicates a need to identify the main failures

\footnotetext{
91 (n 6) 1-24; (n 51) Anna Butenko and Pierre Larouche.

92 (n 51) Prosser, 364-387

93 (n 6) 1-24

94 Council of European Energy Regulators. 2019. CEER Consultation on Dynamic Regulation to Enable Digitalisation of the Energy System - Conclusions paper. C19-DSG-09-03; (n 54).

95 Brian Dollery and Joe Wallis, Market Failure, Government Failure, Leadership and Public Policy (Palgrave Macmillan, 1999) 17; (n 9) Ch 4.2 .

96 See (n 13) Mete and Reins.

97 (n 9) 39

98 Paul Crampton, 'Striking the right balance between competition and regulation: the key is learning from our mistakes' (2002) $<$ https://www.oecd.org/regreform/2503205.pdf> accessed $10 \mathrm{Au}-$ gust 2020 .
}

that prevent the hydrogen market from developing into the energy sector integrator it is envisaged to become. That way, the most appropriate regulatory strategy can be chosen. For this purpose, we identify two market failures that are - at this time - principal barriers to the emergence of a sustainable hydrogen market. ${ }^{95}$ This by no means implies that the hydrogen market is only vitiated by two market failures, more market failures can easily be identified developments costs for example (and the state aid questions some of its remedies may give rise to). ${ }^{96}$

Due to the similarities between the electricity and gas markets on the one hand and the hydrogen market on the other hand - as network industries - existing energy market regulation may serve as inspiration or starting point for designing hydrogen market regulation. This is reflected in the two identified market failures: lack of competition and the risk of internal market fragmentation. These issues have already been extensively regulated in the electricity and gas sectors, and at points, we will refer to electricity market regulation to draw a comparison. The below application of the regulatory strategies (introduced in part 3) to the market failures, gives an idea of the possible advantages and shortcoming of each respective regulatory strategy.

\section{Lack of Competition}

In the absence of regulation, a status-quo may arise in which infrastructure-owners become monopolists with few incentives to welcome competition onto the market. Economies of scale and scope may put off potential entrants from setting up competing networks, further contributing to a lack of competition. ${ }^{97}$ Such considerations also raise concerns regarding competition for the market. In line with the high costs of entering the hydrogen market, infrastructure-owners may want to preclude others from using their network in order to reap higher profits. This may result in consumer harm.

Competition concerns can be tackled in different ways, according to the regulatory regime in place and the cause of the concerns. We have seen in the electricity market, that regulation on third-party access, tariff regulation and unbundling requirements are used to ensure competition on the market. Absent such regulation, a lack of competition may persist. $^{98}$ 


\section{Lack of Competition: Regulatory Strategies and Good Regulation}

In an incentive-based regulatory regime, entry barriers to the market may be lowered in order to attract more players on the market and prevent the emergence of a monopolist. For example, tax incentives could be made available for new producers of green hydrogen. Similarly, the monopolist may be incentivised to act as if they are facing competition. It may, however, be challenging to devise sufficiently effective incentives to ensure that enough players are on the market to curb monopolistic behaviour. Competition could also be stimulated from a perspective of substantive participation: like the prosumers active on the electricity markets, consumer participation could also be stimulated on the hydrogen market. For example, local consumer-owned networks could be incentivised, as well as common ownership of green hydrogen production sites.

In a market-harnessing regime that set the main boundaries for competition between the market operators, lack of competition may be remedied by competition law, in particular by prohibiting abuses of dominant positions. There are obvious downsides to this approach: competition law is enforced ex post and tends to rely on lengthy investigations. ${ }^{99}$ In the electricity market, this concern is mitigated by the existence of sector-specific regulation that applies in addition to the general competition laws. ${ }^{100} \mathrm{~A}$ similar solution for the hydrogen market involves a decision on whether one or two regulatory authorities need to be in charge of enforcing competition and sector-specific rules. Alternatively, a competition for the market scheme may also be able to create competitive market circumstances- the firm that 'won' the market, will have done so due to a competitive plan that it has to put into practice. A risk with this approach is that the selected firm might later not be able to keep its promises.

The establishment of a state-owned enterprise in charge of parts of the hydrogen market is an example of direct government action to safeguard that competition, and social goals are met. Public ownership may be seen as a means to deal with the problem of incomplete contracts. Laws and regulation cannot always fully assure that private parties operate in the public interest. ${ }^{101}$

However, as we have seen in several sectors already, trusting the market to a public company comes with its own pitfalls - for example, the risk of less innovation. ${ }^{102}$ A state-owned company may be inclined to innovate less, counting on the security provided by its shareholder, or because of a lower level of risktaking. Neither do public monopolies prevent the need for regulation. In the Dutch electricity market, for example, regulation is still needed for the stateowned networks. These networks qualify as legal and natural monopolies on which (publicly and privately) owned electricity suppliers are active and regulation is necessary to ensure fair and efficient network access for all market players.

In a command and control regulatory environment, lack of competition may be addressed via unbundling requirements for vertically integrated companies. Unbundling can increase competition, as it may take away incentives for integrated companies to favour their own services all too much or crosssubsidise. Depending on the unbundling requirements in place, the market can benefit from varying levels of transparency. At the same time, unbundling may lead to internal, firm-specific synergy losses. ${ }^{103}$ An additional way of creating opportunities for competition is by forcing network operators to open their network based on the basis of non-discriminatory access and tariffs comparable to the regulation of the electricity sector. Potential negative effects of monopolies, like higher prices or less-than-optimal service, may be tackled by price-controls and legal minimum standards to which firms must adhere, subject to

99 Frances Dethmers and Jonathan Blondeel, 'EU enforcement policy on abuse of dominance: some statistics and facts' (2017) 38 E.C.L.R 4, 147-164.

100 Alexander De Streel, 'The Relationship between Competition Law and Sector Specific Regulation: The case of electronic communications' (2008) xlvii Reflets et perspectives de la vie économique 1, 55-72.

101 Paul De Bijl and Saskia Lavrijssen, 'Bescherming sectoren van publiek belang is makkelijker gezegd dan gedaan' (2017) Me Judice, Radicand Economics; Aandeelhouderschap en publieke belangen van de energietransitie [report] <https:// radicandeconomics.com/wp-content/uploads/2019/10/Rapport -Publieke-belangen-energietransitie-Radicand-Economics-juni -2017.pdf> accessed 10 August 2020.

102 Bernardo Bortolotti et al, 'Innovation at State Owned Enterprises' (2019) <https://core.ac.uk/download/pdf/302358622.pdf>; see also Andrei Shleifer, 'Understanding Regulation' (2005) 11 European Financial Management 4, 439-451.

103 See also Blanka Vitéz and Saskia Lavrijssen, 'The Energy Transition: Democracy, Justice and Good Regulation of the Heat Market' (2020) 13 Energies 5, 1-24. Roland Meyer, 'Vertical Economies and the Costs of Separating Electricity Supply - A Review of Theoretical and Empirical Literature' (2012) 33 The Energy Journal 3, 161-185. 
penalties. ${ }^{104}$ Such considerations highlight the balance that needs to be struck between protecting consumers and providing sufficient incentives for network operators to invest and innovate. ${ }^{105}$ This is not an easy task, and regulatory failures may lead to wrong incentives. It also highlights the need for a sufficiently independent regulator that is able to objectively regulate market players and to supervise whether regulatory rules are applied in a non-discriminatory way.

For lack of competition, existing energy market regulation is certainly relevant but not sufficient. It is unlikely that existing regulation can be cross-applied to the hydrogen market as differences between the hydrogen and the electricity market may stand in the way. Whilst electricity is transported via a dedicated network; the same does not apply in all instances to hydrogen. As we have seen, hydrogen transportation can take place via pipe networks, road, rail or over sea. There may be instances where alternative transportation methods compete. This means that competitive patterns and pressures in the hydrogen market may differ from those in the electricity sector. Equally relevant are storage possibilities. Hydrogen is relatively easy to store compared to electricity. This means that peak and off-peak considerations in the hydrogen market will differ from those in the electricity market. These practical differences between the hydrogen market and electricity market will lead to differences in market regulation, and consequently, differences in how the principles of good regulation need to be taken into account to guarantee good market regulation.

\section{Market Fragmentation}

In the European Union, internal market fragmentation is an unwanted outcome. It occurs when no suc-

\footnotetext{
104 (n 49) 107

105 Laura Abardi and Carlo Cambini, 'Tariff regulation with energy efficiency goals’ (2015) Energy Economics 49, 122-131.

106 See for comparison, Jasper Sluijs, 'Network Neutrality and Internet Market Fragmentation' (2012) 49 CMLRev 5, 1647-1673.

107 See <https://www.iea.org/data-and-statistics/charts/limits-on -hydrogen-blending-in-natural-gas-networks-2018>, accessed 27 August 2020.

108 Christian Buelens et al, 'The economic analysis of state aid: Some open questions' (2017) European Economy Economic Papers, 286
}

cessful harmonisation on a European level takes place, and Member States take divergent policy approaches throughout the EU. ${ }^{106}$ Already different limits apply throughout the Member States for the transport via gas networks of natural gas blended with hydrogen, having the potential of hampering cross-border trade. ${ }^{107}$ Different standards applicable to the production, transport and use of hydrogen may lead to similar results. Market fragmentation may, for example, occur if national networks cannot be connected to enable cross-border trade. Likewise, national hydrogen markets at different stages of development in the EU could also limit cross-border activity.

Because not all Member States will be able to meet their own needs for sustainable hydrogen, and some Member States may produce a surplus, obstacles to the internal market could lead to a less-than-optimal hydrogen market.

\section{Market fragmentation: regulatory strategies and good regulation}

To tackle market fragmentation, the most obvious solution seems cooperation between Member States or the harmonisation of standards and market access rules in European legislation. This has happened in the electricity sector, where in addition to harmonising regulation, the European Union Agency for the Cooperation of Energy Regulators has been established to support cooperation efforts between regulators. Absent harmonisation, the alternative in the hydrogen market would be to rely on Member States to follow each other's' regulatory examples.

Collaboration between different players in a market can be incentivised in different ways. For example, subsidies may be available for (European or regional) collaborative initiatives, or advantageous rules may be put in place for investments in collective arrangements. A strong incentive on collaboration may, however, backfire, in that companies will collaborate on more than what is legally permitted. Subsidies may also create new market failures, leading to distortions on the market. ${ }^{108}$ In terms of the principles of good regulation, an independent regulatory authority in charge of overseeing collaborating market players is perhaps all the more important to counter known anti-competitive risks of collaboration. 
In a market harnessing environment, the government or regulator may enter into contracts with players on the market, requesting them to offer and consider possibilities to interact with others on the market. It may induce interoperability by ensuring that contracts include standards and apply to firms active on the same industry level and potentially lower government costs. A quid-quo-pro between the contracting parties, however, is not immediately obvious unless sanctions are available for those who refuse to facilitate market integration. It also raises the question of the overall efficiency of regulation in the form of contracts. Whilst tailormade outcomes are a benefit of contracting, the transaction costs are high, and at system level, the individual contracts may not lead to optimal solutions. Possibly the benefits of individual contracts may not outweigh any disadvantages of this option. From a perspective of good regulation, a market harnessing regulatory regime may not be optimal.

Another way to prevent market fragmentation is by way of direct government action. In this case, factors that are prone to causing fragmentation, such as infrastructure and standards, are being provided for by the government. In the electricity sector, European regulation designs the market by facilitating crossborder electricity supply through the setting of a target for the installation of cross-border interconnectors that connect transmission grids between two Member States. ${ }^{109}$ The existence of mandatory standards and infrastructure provided for by the government, provide a level of uniformity that prevents at least within a Member State - market fragmentation. Similarly, regulatory action on a European level or the setting up of a transnational regulatory regime could play a role in countering internal market fragmentation. ${ }^{110}$ The formulation of a clear accountability mechanism and a high level of transparency are imperative to increase trust in government action, in particular as this regulatory regime foresees differing roles for the government: directly shaping the market, but also regulating the market this may warrant a regulator with also a high level of political independence.

In a command and control environment, owners of infrastructure may need to adhere to certain criteria that provide for interoperability, and the provision of network-access can be made mandatory subject to fines for non-compliance - like in the electricity sector. The production and distribution of sub-standard hydrogen can be fined administratively. A possible downside of a command and control regulatory approach is that a lot of market information is needed - increasing risks of regulatory capture ${ }^{111}$ - to adopt sufficiently detailed regulation. A command and control environment may also risk hindering innovation by being too restrictive. A command and control environment may lead to detailed, strict and complex rules, that leave little freedom for firms to innovate with new products, services or business strategies. ${ }^{112}$

The above brief discussion of different regulatory regimes in relation to the identified market failures shows that each regime comes with its own advantages and disadvantages. The search for adequate hydrogen market regulation thus implies the weighing of the (dis)advantages of the regulatory regimes against different available options. One way of performing such a weighing exercise relatively risk-free may be by way of experimenting with different regulatory approaches. This will be elaborated on below.

\section{A Regulatory Sandbox for Hydrogen?}

The above thought experiment shows that whilst there are many strategies available to remedy lack of competition and market fragmentation in the hydrogen market, it is difficult to identify all their advantages and disadvantages. This exploration, despite being rudimentary, points to sufficient differences and (dis)advantages of different regimes justifying a more practical, rather than theoretical, approach. And whilst looking at the existing regulation in the electricity sector is certainly a good starting point, copying electricity market regulation will not be sufficient. The hydrogen market has certain unique characteristics that may have as a consequence that regulatory solutions that work in the electricity sector

109 Alex Jacottet, 'Cross-border electricity interconnections for a wellfunctioning EU Internal Electricity Market' (20102) Oxford Energy Comment <https://www.oxfordenergy.org/publications/cross -border-electricity-interconnections-for-a-well-functioning-eu -internal-electricity-market-2/> accessed 10 August 2020; see also the electricity interconnectivity target in Article 4(d)(1) of Regulation 2018/1999 in the Governance of the Energy Union and Climate Action.

110 George Morgan and Mark Thorum, 'Determinants of Transnational Regulatory Regimes' (2016) <https://ssrn.com/abstract $=2863306>$ accessed 19 December 2020 .

111 (n 49) 107-108.

112 ibid 108-109. 
are not equally well-placed in the hydrogen market. This has far-reaching implications in terms of applicable regulations, how to implement the principles of good regulation, the design of a regulator and the roles that the public sector plays in a market that could become crucial for the energy transition.

One way to find out to what extent regulation of the hydrogen market must differ from existing energy regulation is by way of a regulatory sandbox. ${ }^{113}$ Regulatory sandboxes provide for temporary, experimental regulation. The experimental rules often derogate from existing rules. ${ }^{114}$ In the fintech industry, for example, regulatory sandboxes are frequently part and parcel of the regulatory set-up, catering for innovators. In the UK, the Financial Conduct $\mathrm{Au}$ thority (FCA) has been experimenting with regulatory sandboxes since 2015 , allowing firms grouped in cohorts to test new business ideas. ${ }^{115}$ A report on the regulatory sandbox published by the FCA states that there are signs that the sandbox has a positive impact on competition and innovation in the UK financial services market. ${ }^{116}$ Ofgem, the UK's energy regulator, has recently enhanced its regulatory sandbox to allow continuous use of the sandbox. ${ }^{117}$ Ofgem specified that the regulatory sandbox allows for the identification of rules that pose barriers to new products. ${ }^{118}$ These positive experiences do not seem accidental: regulatory sandboxes' positive impact has been confirmed by comparative research. ${ }^{119}$

113 See also (n 13) Mete Reins, 210-231.

114 Sofia Ranchordás, 'Innovation-Friendly Regulation: The Sunset of Regulation the Sunrise of Innovation' (2015) 55 Jurimetrics 2 ; (n 13) Mete and Reins.

115 See FCA, 'Regulatory sandbox' (2020) <https://www.fca.org.uk/ firms/innovation/regulatory-sandbox> accessed 10 August 2020.

116 FCA, 'Regulatory sandbox lessons learned report' (2017) Financial Conduct Authority.

117 See OFGEM, 'Energy Regulation Sandbox: Guidance for Innovators' (2020) <https://www.ofgem.gov.uk/publications-and -updates/energy-regulation-sandbox-guidance-innovators>

118 See OFGEM, 'Insights from running the regulatory sandbox' (2018) <https://www.ofgem.gov.uk/system/files/docs/2018/10/ insights_from_running_the_regulatory_sandbox.pdf $>$ accessed 10 August 2020.

119 Jayoung James Goo Joo-Yeunb Heo, 'The Impact of the Regulatory Sandbox on the FinTech Industry, with a Discussion on the Relation between Regulatory Sandboxes and Open Innovation' (2020) 62 Journal of Open Innovation: Technology, Market, and Complexity 2, 1-18.

120 (n 51) 52-82; Gary Marchant et al., The Growing Gap between Emerging Technologies and Legal-Ethical Oversight (Springer 2011); Mark Fenwick, 'Regulation Tomorrow: What Happens When Technology Is Faster than the Law?' (2017) 6 American University Business Law Review 3, 561-594; (n 114) Sofia Ranchordás.
In markets marked by rapid technological changes, regulatory sandboxes ensure that regulation can quickly adapt. Firms and regulatory authorities can work together in a test-environment to reach optimum outcomes, with limited risks. This is relevant as it is generally accepted that laws and regulation are often lagging behind innovative market developments. ${ }^{120}$ In this regard, a parallel can be drawn with the sustainable hydrogen market. Sufficient possibilities must exist to test ways to increase sustainable hydrogen production and use to allow the market to prosper. This requires a regulatory environment that does not hamper but even encourages, investments in the scaling-up of existing sustainable technologies combined with innovation in new production methods, uses and transportation.

A regulatory sandbox allows for variation and tailored solutions that can be offered to market players. This flexibility can spur innovation. The sustainable hydrogen market is a market that has to benefit from scaling up and innovation to grow in size and become part of the energy transition. The possibility to experiment with different regulatory approaches can absorb risks associated with uncertainties on how the hydrogen market will develop. In addition, the use of a regulatory sandbox also allows for the principles of good regulation to be implemented in the regulation of the market in different ways, allowing for different levels of accountability, independence, transparency and participation.

\section{Conclusion}

This contribution makes a start at assessing how the best regulatory regime can be designed to allow for the hydrogen market to develop into a well-functioning part of the energy sector and to facilitate the integration of renewable energy into the energy system. Because regulation has a strong impact on how a market will develop, it may be disadvantageous to pick a regulatory strategy at a too early stage. Doing so would bring risks of regulatory failure or regulatory disconnect. This means that the development of the market will be hindered by regulation, rather than regulation being a neutral or even stimulating factor for the development of clean energy technologies.

To the national and European legislator, different regulatory strategies are available, ranging from com- 
mand and control regimes to incentive-based regulation. Each regime has unique advantages and disadvantages and can be shaped differently by the principles of good regulation. Combined with the uncertainties on how the hydrogen market will develop, it is challenging to design a good regulatory regime for a well-functioning hydrogen market.

We have also seen that due to the characteristics of hydrogen, lack of competition and market fragmentation may bar the emergence of a well-functioning hydrogen market in the EU and beyond. Existing energy regulation can act as a source of inspiration on how to deal with these market failures - as some lack of competition and market fragmentation have also threatened the emergence of cross-border electricity and gas markets in the EU. Differences between hydrogen and electricity on the hand and hydrogen and gas on the other hand, however, prevent the one on one application of existing energy regulation to the hydrogen market.

It is therefore essential to assess how different types of regulation will play out in practice at an ear- ly stage so as not to hinder the development of the hydrogen market. If limited to theoretical exercises, assessments of regulation may not capture all involved considerations. A more robust assessment is needed that leads to useful insights on what futureproof regulation looks like in the hydrogen market. This may be provided for by way of regulatory sandboxes.

The relevance of a regulatory sandbox lies in the real-life data and insights it offers. Whilst a mere thought experiment can lead to the identification of some (dis)advantages of several different options, real-life experiments will provide more complete and reliable insights. Third-party network access, the use of existing gas infrastructure, unbundling, the connection of local clusters and the role of an independent regulatory authority, are just a few aspects of hydrogen market regulation that can be tested by way of a regulatory sandbox. The principles of good regulation provide a transparent framework to evaluate the outcome of the regulatory sandbox and to assess the pros and cons of different regulatory strategies. 